\title{
Radiological Assessment of the Bauxite Residue Valorization Chain
}

\author{
Andrei Goronovski ${ }^{1}$ and Alan H. Tkaczyk ${ }^{1,2}$
}

${ }^{1}$ Institute of Physics, University of Tartu, W. Ostwaldi 1, 50411 Tartu, Estonia

${ }^{2}$ Institute of Technology, University of Tartu, Nooruse 1, 50411 Tartu, Estonia

goronovski@gmail.com

\section{Keywords}

Bauxite Residue, Residue processing, Gamma-ray spectroscopy, NORM, Uranium, Thorium

\section{Highlights}

- Accumulation of natural radionuclides $\left({ }^{238} \mathrm{U},{ }^{232} \mathrm{Th}\right.$ and their decay products, $\left.{ }^{40} \mathrm{~K}\right)$ during valorization processes of bauxite residue was studied

- It was demonstrated that accumulation of radionuclides in the secondary residues is unlikely to cause risks of elevated radiological exposure to public or workers

- The only material, which had exceeded screening values for natural radionuclides set by European basic safety standard was flue dust formed during iron recovery with reductive smelting

- It was observed that in some of the valorization processes (iron reductive smelting, ionic liquid leaching) portion of the initial radionuclides was recovered with the valuable material

\section{Declaration of interest}

Declarations of interest: none. 


\section{Introduction}

The worldwide production of primary aluminium has been rapidly growing through the $21^{\text {st }}$ century, increasing 2.6 times between 2000 and 2017 ("Statiscal data published at the World Aluminium webpage.," n.d.) to cover industry demand for this light-weight metal. Primary aluminium is produced by electrolysis of metallurgical alumina (aluminium oxide), which in its turn is produced from bauxite ore during the Bayer process, see Figure 1. During the Bayer process, bauxite, an aluminium bearing ore, is dissolved in strong sodium hydroxide solution and subsequently aluminium hydroxide is recovered, which is subsequently converted to aluminium oxide. The remaining elements, mostly insoluble in sodium solution, are washed and usually filtered and end up in the Bauxite Residue (BR), also called 'red mud'. BR is produced at the rates of 1 to 1.5 ton on average per ton of alumina, totaling up to 150 Mtons annually worldwide (Evans, 2016). Historically, bauxite residue has been treated as a waste material and in some places used to be discharged in the sea or stockpiled in special Bauxite Residue Disposal Areas (BRDAs) (Power et al., 2009). The growing volume of the produced BR requires new land areas for the BRDAs and puts additional economic burden on alumina plants. At the same time, potential failure of a BRDA can be dangerous to nearby population and hazardous to the environment, similarly to Ajka accident in Hungary in 2010 (Ruyters et al., 2011), (Winkler et al., 2018) and storage failure in Dahegou Village in China in 2016 (Frik, 2016).

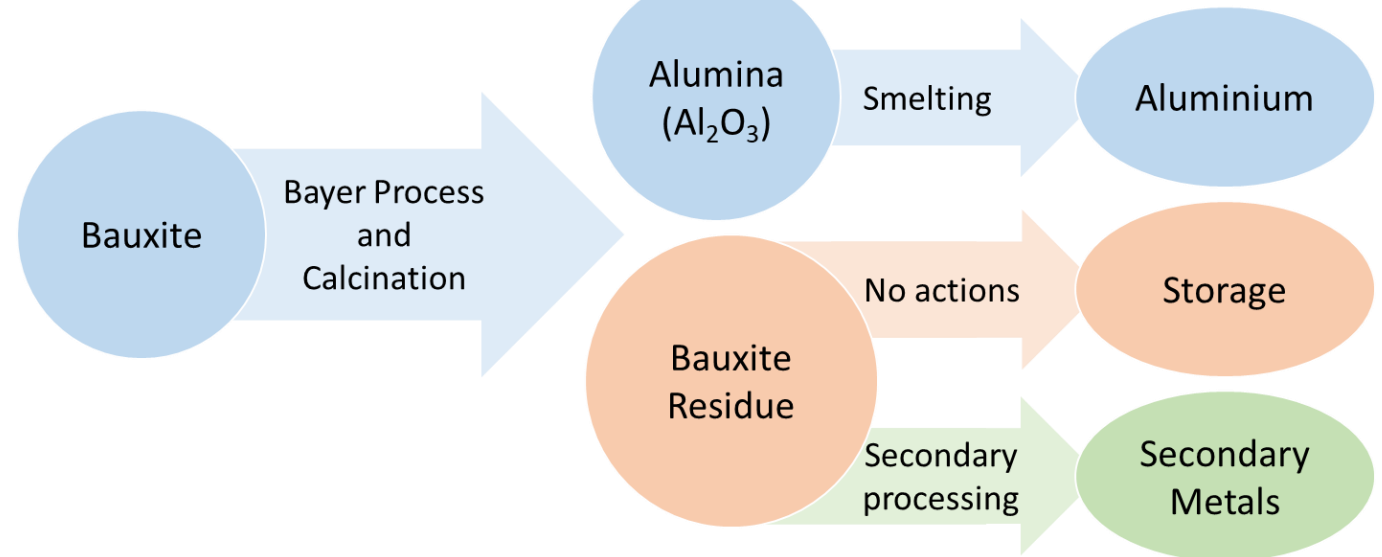

Figure 1: During the Bayer process, bauxites are separated into alumina and Bauxite Residue (BR). BR can be landfilled or further processed to recover iron, aluminium, titanium or other valuable materials.

As a result, there is a significant interest towards development of BR valorization methods, such as development of BR containing construction materials (bricks, cement, inorganic polymers (Evans, 2016; Joyce et al., 2018; Raj et al., 2013)) and recovery of valuable metals from BR (Bonomi et al., 2016). BR is rich in iron, aluminium, titanium and Rare Earth Elements (REE), as presented in Table 1, as well as has elevated concentration of naturally occurring 
radionuclides. Bauxite Residue radionuclide content can vary significantly based on the origins of bauxites, possible concentrations are $100-3000 \mathrm{~Bq} / \mathrm{kg}$ for uranium and thorium series, $10-100 \mathrm{~Bq} / \mathrm{kg}$ for ${ }^{40} \mathrm{~K}$ (IAEA, 2003).

Table 1: Typical chemical composition of the bauxite residue.

\begin{tabular}{|c|c|}
\hline $\begin{array}{c}\text { Component } \\
\mathrm{Fe}_{2} \mathrm{O}_{3}\end{array}$ & $20-45 \%$ (INTERNATIONAL ALUMINIUM INSTITUTE, 2015) \\
\hline $\mathrm{Al}_{2} \mathrm{O}_{3}$ & $10-22 \%$ (INTERNATIONAL ALUMINIUM INSTITUTE, 2015) \\
\hline $\mathrm{TiO}_{2}$ & $4-20 \%$ (INTERNATIONAL ALUMINIUM INSTITUTE, 2015) \\
\hline $\mathrm{CaO}$ & $0-14 \%$ (INTERNATIONAL ALUMINIUM INSTITUTE, 2015) \\
\hline $\mathrm{SiO}_{2}$ & $5-30 \%$ (INTERNATIONAL ALUMINIUM INSTITUTE, 2015) \\
\hline $\mathrm{Na}_{2} \mathrm{O}$ & $2-8 \%$ (INTERNATIONAL ALUMINIUM INSTITUTE, 2015) \\
\hline REE & $0.1-1 \%$ (Bonomi et al., 2016) \\
\hline
\end{tabular}

During a metallurgical process, the valuable fraction of the initial raw material is recovered, while the remaining materials are accumulated in the waste or residue product. For instance, in the Bayer process implemented at the Aluminium of Greece plant, most of the radionuclides presented in the bauxites end up in the $B R$, and their concentration is increased 1.7-2.5 times per unit mass (Goronovski et al., 2018).

Despite a considerable radionuclide accumulation ratio, BR produced at Aluminium of Greece plant (AOG) is not considered radiologically hazardous, as the radionuclide concentrations remain below screening values set in the European Basic Safety Standard: $1000 \mathrm{~Bq} / \mathrm{kg}$ for ${ }^{232} \mathrm{U}$ and ${ }^{234} \mathrm{Th}$ decay series nuclides and 10000 for ${ }^{40} \mathrm{~K}$ (European Parliament, 2014). If the natural radionuclide content in a material remains below these values, then the material is unlikely to cause elevated radiological exposure to humans and environment.

Secondary processing of the BR might further increase radionuclide concentration in the newly produced residues, and therefore it is important to investigate behavior of these radionuclides and to ensure safety of the workers and environment. In the current article, the following valorization processes have been studied: (1) iron smelting; (2) iron roasting; (3) alkali leaching of aluminium; (4) acidic recovery of trace metals; (5) ionic liquid leaching.

\section{Description of the investigated processes}

\subsection{Iron smelting:}

An electric arc furnace was used to recover pig iron from the BR. In this process carbon was used to convert iron oxides to metallic iron at high temperatures ( $\left.1500-1700^{\circ} \mathrm{C}\right)$ (Tam et al., 2017). As a result, iron was recovered in the form of pig iron and the rest of the materials were separated in the form of slag, see Figure 2. Fluxing materials (lime, $\mathrm{SiO}_{2}$, etc) can be added to the process for more efficient separation between pig iron and slag. A small amount 
of flue dust was produced as an additional secondary waste product, which can potentially be recycled by other industries (Ruiz et al., 2007), (De Araújo and Schalch, 2014).

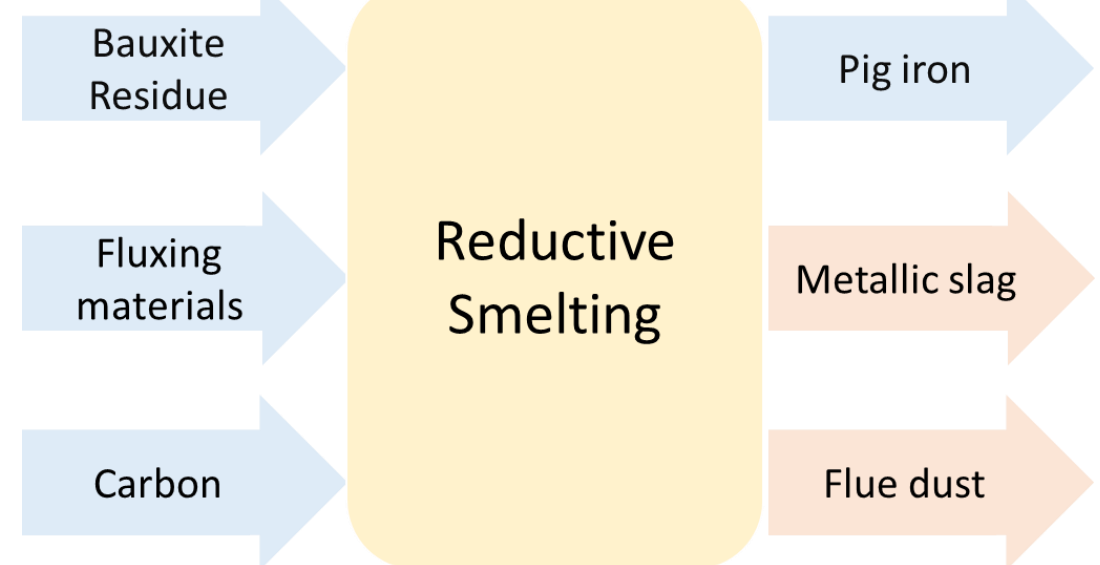

Figure 2: Reductive smelting of BR schematics.

\subsection{Iron roasting}

Iron roasting is an alternative method to recover iron from $B R$ and is schematically described in Figure 3 (Cardenia et al., 2017). Roasting was performed in order to convert iron within BR into a magnetic form. During this process, $\mathrm{BR}$ was mixed with metallurgical coke and $\mathrm{Na}_{2} \mathrm{CO}_{3}$ was added as a fluxing material. The mixture produced was roasted at $1000^{\circ} \mathrm{C}$ to create cinders (sodium aluminates). The cinders were milled and leached with water; the resulting particles are subjected to magnetic separation multiple times with different currents going through the magnet. As a result, most of the iron was recovered in the form of magnetic fractions and the remaining materials were found in the non-magnetic fraction.

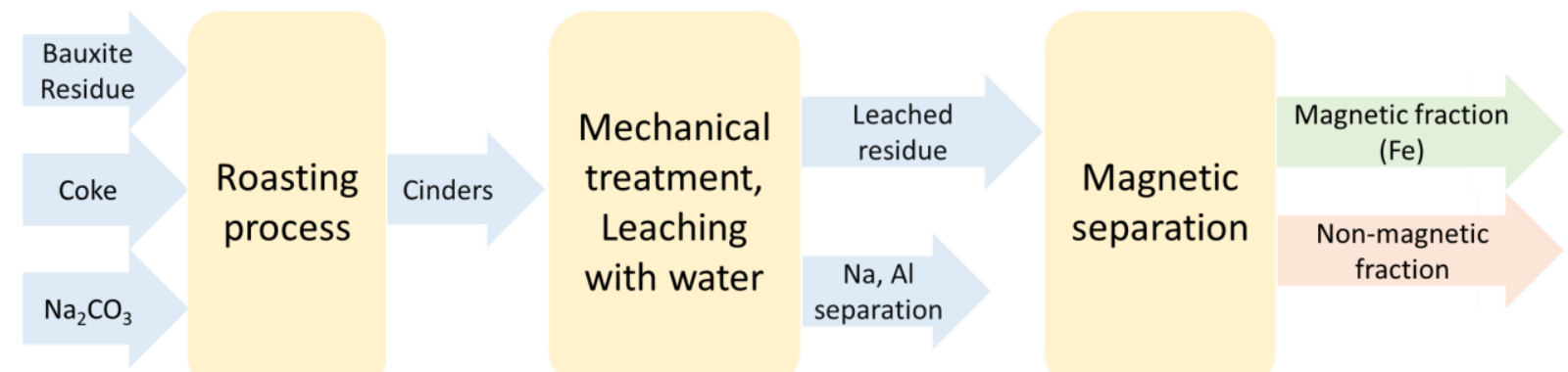

Figure 3: Roasting and magnetic separation of iron from the BR.

\subsection{Recovery of aluminia with alkali leaching}

Similarly to iron roasting, during this process BR was mixed with sodium carbonate and heated to $800-1100^{\circ} \mathrm{C}$ to form cinders (Bonomi et al., 2016). Next, sodium hydroxide was used to dissolve and leach sodium aluminates, leaving rest of the materials in the form of residue as presented in Figure 4. 


\begin{tabular}{|c|c|c|c|c|}
\hline $\begin{array}{l}\text { Bauxite } \\
\text { Residue }\end{array}$ & Roasting & $\begin{array}{c}\mathrm{NaOH}, \\
\mathrm{H}_{2} \mathrm{O}\end{array}$ & & $\begin{array}{c}\text { Leachate } \\
(\mathrm{NaOH}+\mathrm{Al})\end{array}$ \\
\hline $\mathrm{Na}_{2} \mathrm{CO}_{3}$ & & Cinders & & $\begin{array}{l}\text { Leachate } \\
\text { residue }\end{array}$ \\
\hline
\end{tabular}

Figure 4: Pyro-metallurgical roasting of the BR schematics.

\subsection{Acidic recovery of trace metals from the neutralized $B R$}

$\mathrm{BR}$ was first neutralized with $\mathrm{CO}_{2}$ in order to reduce $\mathrm{pH}$ and thus consumption of acid, as described elsewhere (Rivera et al., 2017). Then mineral acids $\left(\mathrm{H}_{2} \mathrm{SO}_{4}, \mathrm{HNO}, \mathrm{HCl}\right)$ were used to dissolve primary and trace metals from the $\mathrm{BR}$. The resulting solid residues were analyzed for the radionuclides.

Bauxite

Residue

$\mathrm{CO}_{2}$

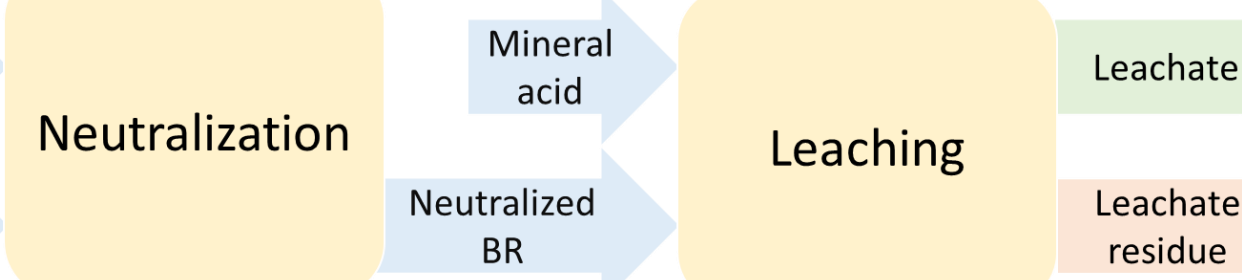

residue

Figure 5: Acidic recovery of trace metals from the neutralized BR.

\subsection{Ionic liquid leaching}

Ionic liquids are solvents consisting purely of ions, which can be used as an alternative to mineral acids in dissolving BR and recovering variety of metals, including REE. [Emim] $\left[\mathrm{H}_{2} \mathrm{SO}_{4}\right]$ was the ionic liquid used to dissolve BR (Bonomi et al., 2017). Valuable metals dissolve and end up in the leachate, while the insoluble fractions are filtered and considered as residue. 
$[\mathrm{Emim}]\left[\mathrm{H}_{2} \mathrm{SO}_{4}\right]$

Neutralized BR
Leachate

\section{Leaching}

\section{Leachate}

residue

Figure 6: Leaching with ionic liquid.

\section{Measurement methods}

Two high purity germanium detectors were used in the current study: GEM- 35200 (EG\&G Ortec $^{\circledR}$ ) coaxial detector and BE3830P (supplied by CANBERRA ${ }^{\circledR}$ ). The following radionuclides were studied: ${ }^{226} \mathrm{Ra}$ (decay product of ${ }^{238} \mathrm{U}$ ), ${ }^{228} \mathrm{Ra}$ and ${ }^{228} \mathrm{Th}$ (decay products of ${ }^{232} \mathrm{Th}$ ) by their decay products (as presented in Table 2). Secular equilibrium was assumed between measured and the nuclides presented (the probes were kept intactly sealed for a month after preparation to ensure secular equilibrium is achieved).

Calibration was performed using RGU-1 and RGTh-1 reference materials certified by IAEA (IAEA, 1987).

Table 2: Following gamma were lines used in the measurements. In brackets, daughter nuclides that were used to determine parent nuclide activity are provided.

\begin{tabular}{|c|c|}
\hline Isotope & Gamma lines [keV] \\
\hline & 241.99 \\
${ }^{226} \mathrm{Ra}\left({ }^{\mathbf{2 1 4}} \mathbf{P b}\right)$ & 295.22 \\
& 351.93 \\
\hline${ }^{228} \mathrm{Ra}\left({ }^{\mathbf{2 1 2}} \mathbf{P b}\right)$ & 238.63 \\
\hline & 338.32 \\
${ }^{228} \mathrm{Th}\left({ }^{\mathbf{2 2 8}} \mathrm{Ac}\right)$ & 911.19 \\
& 968.96 \\
\hline
\end{tabular}

\subsection{Sample preparation}

Samples were dried at $105^{\circ} \mathrm{C}$ and then were tightly sealed in metallic containers to avoid radon leakage. In case significant sample volume was available, $55.5 \mathrm{~cm}^{3}$ aluminium container was tightly filled. However, most of the samples' mass was in the order of 1-2 grams, due to the fact that experiments were performed at laboratory scale. These samples were mixed with larger volume of epoxy resin and homogenized. After solidification, the samples had the same geometry and a similar matrix to the standard materials. Possible differences in density and matrix were corrected with EFFTRAN model (Vidmar, 2005).

Residues produced in liquid form were dried and then prepared similarly to the solid samples. 


\section{Results}

Bauxite Residue coming from the AoG plant was used in the current study. The radiological properties of this BR have been previously discussed in (Goronovski et al., 2018) and are summarized in the Table 3 . The secondary residues produced after recovery of valuable metals from BR are presented in this work. Altogether with measured radionuclide concentrations (all the uncertainties are reported at $2 \sigma$ confidence level), enrichment factors are provided $\left(C_{R}\right.$, see equation 1$)$ as the ratio between activity concentration of secondary residue over $B R$.

$$
C_{R}=\frac{A_{\text {residue }}}{A_{B R}}
$$

Table 3: Mean radionuclide content in BR from AoG (Goronovski et al., 2018). Uncertainties are reported at $2 \sigma$.

\begin{tabular}{|c|c|c|}
\hline Isotope series & Isotope & $\begin{array}{c}\text { Mean concentration } \\
{[\mathrm{Bq} / \mathrm{kg}]}\end{array}$ \\
\hline${ }^{238} \mathrm{U}$ & ${ }^{226} \mathrm{Ra}\left({ }^{214} \mathrm{~Pb}\right)$ & $170 \pm 2$ \\
\hline \multirow{2}{*}{${ }^{232} \mathrm{Th}$} & ${ }^{228} \mathrm{Ra}\left({ }^{228} \mathrm{Ac}\right)$ & $431 \pm 7$ \\
\cline { 2 - 3 } & ${ }^{228} \mathrm{Th}\left({ }^{212} \mathrm{~Pb}\right)$ & $404 \pm 15$ \\
\hline${ }^{40} \mathrm{~K}$ & ${ }^{40} \mathrm{~K}$ & $26 \pm 8$ \\
\hline
\end{tabular}

\subsection{Reductive smelting}

Measurement results for residues produced with reductive smelting are summarized in the Table 4. Residues (called slags, S1.1, S1.2, S1.3) from three experiments have been analyzed, while S1.1D is a flue dust sample produced during the first experiment and S1.3V is a vanadium sample recovered from pig iron during experiment 3.

Significant difference in the radionuclide accumulation ratios is explained by the differences in the amounts of fluxing materials (see Figure 2), no fluxes were used in experiment 1 , and 5:1 BR to flux ratio was used in the experiments 2 and 3 (further information is available in the Appendix A).

As a result, in the residue $\mathrm{S} 1.1$ radionuclide accumulation ratio was rather high and for ${ }^{228} \mathrm{Th}$ concentration reached $1013 \pm 31.6 \mathrm{~Bq} / \mathrm{kg}$, making it potentially hazardous if produced at large scale (BSS screening value of $1000 \mathrm{~Bq} / \mathrm{kg}$ is set for ${ }^{228} \mathrm{Th}$ ).

Optimization of the valorization process resulted in experiments 2 and 3, where fluxes were added and the mean radionuclide accumulation ratio was $1.6-1.7$. These residues posed no potential radiological hazard, as the radionuclide concentrations remained below screening limits set in the EU BSS (European Parliament, 2014). The analyzed flue dust sample has 
shown considerable accumulation of ${ }^{210} \mathrm{~Pb}$, which is a common problem for iron processing facilities due to the volatile properties of lead at elevated temperatures (Jia, 2013). The dust produced is hazardous from radiological perspective, however, it can be processed as discussed in chapter 2.1. Vanadium sample (S1.3V), which was recovered by oxidization from pig iron has shown only minor presence of ${ }^{228} \mathrm{Th}$.

In the sample S1.1 similar amount of ${ }^{40} \mathrm{~K}$ as in the BR was detected. In all the rest measured samples ${ }^{40} \mathrm{~K}$ concentration remained below Minimum Detectable Amount (MDA).

Table 4: Radionuclide concentration in the secondary residues produced by reductive smelting. Results in brackets show radionuclide accumulation compared to BR.

\begin{tabular}{|c|c|c|c|c|c|}
\hline \multirow{2}{*}{ Isotope } & \multicolumn{5}{|c|}{ Radionuclide concentration [Bq/kg d.w. ${ }^{1}$ ] } \\
\cline { 2 - 6 } & $\mathbf{S ~ 1 . 1}$ & $\mathbf{S ~ 1 . 2}$ & $\mathbf{S ~ 1 . 3}$ & S 1.1D & S 1.3V \\
\hline${ }^{226} \mathrm{Ra}$ & $\begin{array}{c}397.3 \pm 4.5 \\
(2.3)\end{array}$ & $\begin{array}{c}289.4 \pm 10.6 \\
(1.7)\end{array}$ & $\begin{array}{c}284.2 \pm 16.0 \\
(1.7)\end{array}$ & $<333$ & $<129$ \\
\hline${ }^{228} \mathrm{Ra}$ & $\begin{array}{c}905.9 \pm 11.1 \\
(2.1)\end{array}$ & $\begin{array}{c}682.2 \pm 24.5 \\
(1.6)\end{array}$ & $\begin{array}{c}680.2 \pm 44.0 \\
(1.6)\end{array}$ & $<711$ & $<222$ \\
\hline${ }^{228} \mathrm{Th}$ & $\begin{array}{c}1013 \pm 31.6 \\
(2.5)\end{array}$ & $\begin{array}{c}686.0 \pm 23.8 \\
(1.7)\end{array}$ & $\begin{array}{c}680.0 \pm 42.4 \\
(1.7)\end{array}$ & $<240$ & $188.1 \pm 14.1$ \\
\hline${ }^{40} \mathrm{~K}$ & $27.5 \pm 11.2$ & $<231$ & $<150$ & $<3740$ & $<914$ \\
\hline${ }^{210} \mathrm{~Pb}$ & - & - & - & $2436.4 \pm 476.2$ & - \\
\hline $\begin{array}{c}\text { Mean } \\
\text { Accumulation }\end{array}$ & 2.3 & 1.7 & 1.6 & - & - \\
\hline
\end{tabular}

\subsection{Reductive roasting}

Samples produced during one single reductive roasting experiment were analyzed and results were summarized in the Table 5. Two steps of iron recovery with magnetic separation were performed (S2.1 and S2.2) under different currents of 1 and 5 A respectively. The remaining materials ended up in the non-magnetic fraction (S2.3), considered as a residue in this process and additionally metallurgical coal sample, which was added during roasting, was studied. Resulting residue did not show significant radionuclide concentration change compared to the BR (mean accumulation ratio - 1.1), while recovered portions of iron (S2.1 and S2.2) had considerable accumulation (1.4 and 1.5 respectively) compared to the BR. This leads to a hypothesis that significant amounts of radionuclides in the BR are associated with iron. This would also explain previous observation, than only minor portion of uranium is dissolved during the Bayer process (Goronovski et al., 2018), since iron is considered to be inert material in the Bayer process (Vind et al., 2017).

\footnotetext{
${ }^{1}$ d.w. - dry weight.

${ }^{2}$ Mean accumulation rate was calculated for ${ }^{226} \mathrm{Ra},{ }^{228} \mathrm{Ra}$ and ${ }^{228} \mathrm{Ra} .{ }^{40} \mathrm{~K}$ was detected only in one sample, for the rest MDA values are provided.
} 
Analysis of metallurgical coal has shown no considerable radionuclide input from this material.

Table 5: Results of a single experiment of reductive roasting. Two steps of magnetic separation have been performed and the residue is presented in the form of a nonmagnetic fraction.

\begin{tabular}{|c|c|c|c|c|}
\hline \multirow{2}{*}{ Isotope } & \multicolumn{4}{|c|}{ Radionuclide concentration [Bq/kg d.w.] } \\
\cline { 2 - 5 } & $\mathbf{S 2 . 1}$ & $\mathbf{S 2 . 2}$ & $\mathbf{S 2 . 3}$ & Coal \\
\hline \multirow{2}{*}{${ }^{226} \mathrm{Ra}$} & $\begin{array}{c}247.5 \pm 8.4 \\
(1.5)\end{array}$ & $\begin{array}{c}246.4 \pm 32 \\
(1.5)\end{array}$ & $\begin{array}{c}181.9 \pm 16.4 \\
(1.1)\end{array}$ & $<26.4$ \\
\hline \multirow{2}{*}{${ }^{228} \mathrm{Ra}$} & $\begin{array}{c}630.4 \pm 34.8 \\
(1.5)\end{array}$ & $\begin{array}{c}606.4 \pm 59.4 \\
(1.4)\end{array}$ & $\begin{array}{c}490.5 \pm 37.6 \\
(1.1)\end{array}$ & $<44.5$ \\
\hline \multirow{2}{*}{${ }^{228} \mathrm{Th}$} & $\begin{array}{c}632.2 \pm 37.6 \\
(1.6)\end{array}$ & $\begin{array}{c}551.6 \pm 44.4 \\
(1.4)\end{array}$ & $\begin{array}{c}385.4 \pm 28.2 \\
(1.0)\end{array}$ & $<19.9$ \\
\hline${ }^{40} \mathrm{~K}$ & $<107$ & $<76.4$ & $<338$ & $<184$ \\
\hline Mean & 1.5 & 1.4 & 1.1 & - \\
\hline
\end{tabular}

\subsection{Recovery of aluminia with alkali leaching}

Results of the experiments on the process optimization are presented in the Table 6. During these experiments, residue masses were in the order of $0.1-0.5$ grams. In order to obtain measurable sample mass, materials from multiple experiments were mixed to obtain one measurement sample (S3.1 and S3.2), where S3.1C and S3.2C are cinders and S3.1R and S3.2R are corresponding residues (see Figure 4 for more details).

In both measured cinder samples, similar mean radionuclide dilution (mean decrease of $10 \%$ ) was observed due to addition of sodium carbonate. In the residue samples, $20 \%$ higher average radionuclide content compared to BR was observed in the first batch and $30 \%$ in the second. There was also considerable difference in the quantity of ${ }^{228} \mathrm{Ra}$ and ${ }^{228} \mathrm{Th}$ in the sample S3.2R. These isotopes are products of the thorium decay chain; however, they have different chemical properties and might behave differently during chemical processing.

Table 6: Radionuclide concentration in the cinders and residues produced in preliminary aluminium leaching experiments.

\begin{tabular}{|c|c|c|c|c|}
\hline \multirow{2}{*}{ Isotope } & \multicolumn{4}{|c|}{ Radionuclide concentration [Bq/kg d.w.] } \\
\cline { 2 - 5 } & $\mathbf{S 3 . 1 C}$ & $\mathbf{S 3 . 1 R}$ & $\mathbf{S 3 . 2 C}$ & $\mathbf{S 3 . 2 R}$ \\
\hline \multirow{2}{*}{${ }^{226} \mathrm{Ra}$} & $154.8 \pm 7.4$ & $192.3 \pm 23.2$ & $149.2 \pm 4.2$ & $125.7 \pm 12.1$ \\
& $(0.9)$ & $(1.1)$ & $(0.9)$ & $(1.3)$ \\
\hline \multirow{2}{*}{${ }^{228} \mathrm{Ra}$} & $389.1 \pm 16.2$ & $489.4 \pm 46.8$ & $369.1 \pm 10.0$ & $272.4 \pm 23.4$ \\
& $(0.9)$ & $(1.1)$ & $(0.9)$ & $(1.2)$ \\
\hline${ }^{228} \mathrm{Th}$ & $388.8 \pm 15.4$ & $499.2 \pm 32$ & $370.9 \pm 12.9$ & $338.1 \pm 19.1$ \\
\hline
\end{tabular}




\begin{tabular}{|c|c|c|c|c|}
\hline & $(1.0)$ & $(1.2)$ & $(0.9)$ & $(1.4)$ \\
\hline${ }^{40} \mathrm{~K}$ & $<165$ & $<768$ & $<106$ & $<178$ \\
\hline Mean & $\mathbf{0 . 9}$ & $\mathbf{1 . 2}$ & $\mathbf{0 . 9}$ & $\mathbf{1 . 3}$ \\
\hline
\end{tabular}

The next set of experiments was conducted using BR slag as an input material. Iron was initially removed from BR using the smelting method as discussed in chapter 2.1 and 5:2 BR to flux ratio. Aluminium was recovered from the slag produced by alkali leaching and the radionuclide content of residues has been studied. Measurement results for slag and residues produced in multiple experiments are presented in Table 7. In the experiments material quantitates were used in the order of 1 - 3 grams, and thus every measured sample corresponds to a single experiment (more details about experimental conditions are available in the Appendix A). In the resulting residues, mean radionuclide increase by $20 \%-30 \%$ was observed. The radionuclide content remained similar to the slag (S3.slag) and remained consistent between different experiments, showing no potential influence of experimental parameters presented in the Appendix A.

Activity concentration of ${ }^{228} \mathrm{Ra}$ and ${ }^{228} \mathrm{Th}$ is similar in the studied residues, however residues S3.2R - S3.9R show lower accumulation ratio of ${ }^{228} \mathrm{Ra}$ than the other nuclides. This is caused by initially lower measured content of ${ }^{228} \mathrm{Ra}$ in BR (as presented in Table 3).

Table 7: BR slag used as a source material for aluminium recovery and corresponding residues. Results in brackets show radionuclide accumulation compared to the initial BR.

\begin{tabular}{|c|c|c|c|c|c|c|c|}
\hline \multirow{2}{*}{ Isotope } & \multicolumn{7}{|c|}{ Radionuclide concentration [Bq/kg d.w.] } \\
\cline { 2 - 8 } & S3.slag & S3.3R & S3.4R & S3.5R & S3.6R & S3.7R & S3.8R \\
\hline \multirow{2}{*}{${ }^{226} \mathbf{R a}$} & $216.1 \pm 12.6$ & $231.3 \pm 13.0$ & $229.5 \pm 12.8$ & $230.1 \pm 13.0$ & $222.2 \pm 9.7$ & $223.6 \pm 12.0$ & $219.9 \pm 12.8$ \\
& $(1.3)$ & $(1.4)$ & $(1.4)$ & $(1.4)$ & $(1.3)$ & $(1.3)$ & $(1.2)$ \\
\hline \multirow{2}{*}{${ }^{228} \mathbf{R a}$} & $\begin{array}{c}508.1 \pm 33.7 \\
(1.2)\end{array}$ & $\begin{array}{c}516.4 \pm 34.2 \\
(1.2)\end{array}$ & $\begin{array}{c}537.7 \pm 35.2 \\
(1.2)\end{array}$ & $\begin{array}{c}516.1 \pm 34.4 \\
(1.2)\end{array}$ & $\begin{array}{c}492.8 \pm 28.6 \\
(1.1)\end{array}$ & $\begin{array}{c}522.4 \pm 29.0 \\
(1.2)\end{array}$ & $\begin{array}{c}521.4 \pm 34.6 \\
(1.2)\end{array}$ \\
\hline \multirow{2}{*}{${ }^{228} \mathrm{Th}$} & $528.6 \pm 33.2$ & $532.9 \pm 33.4$ & $527.4 \pm 33.2$ & $527.5 \pm 33.2$ & $518.1 \pm 28.9$ & $519.2 \pm 30.6$ & $528.0 \pm 33.0$ \\
& $(1.3)$ & $(1.3)$ & $(1.3)$ & $(1.3)$ & $(1.3)$ & $(1.3)$ & $(1.3)$ \\
\hline${ }^{40} \mathbf{K}$ & $<193$ & $<228$ & $<226$ & $<238$ & $<163$ & $<214$ & $<226$ \\
\hline Mean & 1.3 & 1.3 & 1.3 & 1.3 & 1.2 & 1.3 & 1.3 \\
\hline
\end{tabular}

\subsection{Acidic recovery of trace metals from neutralized $B R$}

This method was used to recover primary metals ( $\mathrm{Fe}, \mathrm{Al}, \mathrm{Ti}$ ) altogether with trace elements (REE and Sc). Three different acids were tested and radionuclide content of the produced residues is summarized in Table 8: $\mathrm{HNO}_{3}(\mathrm{~S} 4.1), \mathrm{H}_{2} \mathrm{SO}_{4}$ (S4.2) and $\mathrm{HCl}$ (S4.3). Metal recovery efficiency for these experiments ( $\mathrm{Fe}, \mathrm{Al}, \mathrm{Ti}, \mathrm{REE}, \mathrm{Sc}$ ) is presented elsewhere (Rivera et al., 2017). The mean increase of the radionuclide content did not exceed $20 \%$ compared to the 
initial BR. It is expected, that portion of radionuclides was dissolved and leached with valuable metals. This to be confirmed in future experiments with the leachate samples.

Table 8: Residues produced during 3 experiments to recover primary and trace metals with mineral acids. Results in brackets show radionuclide accumulation compared to the initial BR.

\begin{tabular}{|c|c|c|c|}
\hline \multirow{2}{*}{ Isotope } & \multicolumn{3}{|c|}{ Radionuclide concentration [Bq/kg d.w.] } \\
\cline { 2 - 4 } & $\mathbf{S 4 . 1}$ & $\mathbf{S 4 . 2}$ & $\mathbf{S 4 . 3}$ \\
\hline \multirow{2}{*}{${ }^{226} \mathrm{Ra}$} & $204.0 \pm 9.5$ & $198.8 \pm 8.8$ & $203.4 \pm 7.8$ \\
& $(1.2)$ & $(1.2)$ & $(1.2)$ \\
\hline \multirow{2}{*}{${ }^{228} \mathrm{Ra}$} & $524.0 \pm 75.2$ & $463.4 \pm 28.0$ & $514.8 \pm 29.0$ \\
& $(1.2)$ & $(1.1)$ & $(1.2)$ \\
\hline \multirow{2}{*}{${ }^{228} \mathrm{Th}$} & $465.0 \pm 75.2$ & $430.9 \pm 26.8$ & $529.3 \pm 31.0$ \\
& $(1.2)$ & $(1.1)$ & $(1.3)$ \\
\hline${ }^{40} \mathrm{~K}$ & $<117$ & $<123$ & $<105$ \\
\hline Mean & 1.2 & 1.1 & 1.2 \\
\hline
\end{tabular}

\subsection{Ionic liquid leaching}

The radionuclide concentrations for nine residues (S5.1 - S5.9) produced after BR treatment with [Emim] $\left[\mathrm{H}_{2} \mathrm{SO}_{4}\right]$ are presented in Table 9 and Table 10. Metal recovery efficiency for these experiments ( $\mathrm{Fe}, \mathrm{Al}, \mathrm{Ti}, \mathrm{REE}, \mathrm{Na}$ ) is presented elsewhere (Bonomi et al., 2018). For residues S5.7 - S5.9 corresponding leachate solution were also analyzed (S5.7I - S5.9l).

Produced residues show significant difference in the mean radionuclide accumulation ratio, ranging between 1.0 - 1.5. No correlation with the experimental setup conditions were observed (see Appendix A for more details on the experimental conditions). Additionally, in two of the experiments (S5.1 and S5.3) decrease in ${ }^{228}$ Th content was observed, which can be explained by potential leaching of this nuclide.

In the residues S5.1 - S5.6 and S5.9 ${ }^{226} \mathrm{Ra}$ accumulation ratio is higher than for the thorium series nuclides ( ${ }^{228} \mathrm{Ra}$ and $\left.{ }^{228} \mathrm{Th}\right)$.

Table 9: Radionuclide concentration in the residues produced after BR was leached with ionic liquid. Results in brackets show radionuclide accumulation compared to the initial BR.

\begin{tabular}{|c|c|c|c|c|c|c|}
\hline \multirow{2}{*}{ Isotope } & \multicolumn{7}{|c|}{ Radionuclide concentration [Bq/kg d.w.] } \\
\cline { 2 - 7 } & $\mathbf{S 5 . 1}$ & $\mathbf{S 5 . 2}$ & $\mathbf{S 5 . 3}$ & S5.4 & S5.5 & S5.6 \\
\hline \multirow{2}{*}{${ }^{226} \mathrm{Ra}$} & $204.2 \pm 12.4$ & $184.1 \pm 12.1$ & $236.3 \pm 16.2$ & $263.0 \pm 16.0$ & $213.6 \pm 23.2$ & $325.7 \pm 33.4$ \\
& $(1.2)$ & $(1.1)$ & $(1.4)$ & $(1.6)$ & $(1.3)$ & $(1.9)$ \\
\hline \multirow{2}{*}{${ }^{228} \mathrm{Ra}$} & $451.1 \pm 26.6$ & $446.2 \pm 25.0$ & $462.0 \pm 33.3$ & $559.2 \pm 39.2$ & $459.0 \pm 44.1$ & $577.9 \pm 66.0$ \\
& $(1.0)$ & $(1.0)$ & $(1.1)$ & $(1.3)$ & $(1.1)$ & $(1.3)$ \\
\hline
\end{tabular}




\begin{tabular}{|c|c|c|c|c|c|c|}
\hline${ }^{228} \mathrm{Th}$ & $\begin{array}{c}305.1 \pm 17.4 \\
(0.8)\end{array}$ & $\begin{array}{c}416.1 \pm 20.6 \\
(1.0)\end{array}$ & $\begin{array}{c}353.3 \pm 21.8 \\
(0.9)\end{array}$ & $\begin{array}{c}520.9 \pm 34.2 \\
(1.3)\end{array}$ & $\begin{array}{c}499.2 \pm 36.7 \\
(1.2)\end{array}$ & $\begin{array}{c}540.3 \pm 44.6 \\
(1.3)\end{array}$ \\
\hline${ }^{40} \mathrm{~K}$ & $<338$ & $<313$ & $<492$ & $<76$ & $<292$ & $<537$ \\
\hline Mean & 1.0 & 1.1 & 1.1 & 1.4 & 1.2 & 1.5 \\
\hline
\end{tabular}

Liquid leachate samples S5.7I - S5.8l show presence of trace amounts of ${ }^{228} \mathrm{Ra}$ and ${ }^{226} \mathrm{Ra}$ in S5.9l. Current experiments could not confirm leaching of ${ }^{228}$ Th due to high MDA value which are explained by small masses of the samples. Leachate results are to be treated indicatively, as these are intermediate products that should be further processed to separate valuable metals.

Table 10: In the experiments 7 - 9 liquid leachate samples were analyzed additionally to the solid residues. Results in brackets show radionuclide accumulation compared to the initial

BR.

\begin{tabular}{|c|c|c|c|c|c|c|}
\hline \multirow{2}{*}{ Isotope } & \multicolumn{3}{|c|}{ Radionuclide concentration [Bq/kg } & \multicolumn{2}{c|}{ Radionuclide concentration [Bq/l] } \\
\cline { 2 - 7 } & $\mathbf{S 5 . 7 s}$ & $\mathbf{S 5 . 8 s}$ & $\mathbf{S 5 . 9 s}$ & S5.7I & S5.8I & S5.9I \\
\hline${ }^{226} \mathrm{Ra}$ & $\begin{array}{c}241.2 \pm 32 \\
(1.4)\end{array}$ & $\begin{array}{c}206.3 \pm 10.4 \\
(1.2)\end{array}$ & $\begin{array}{c}263.6 \pm 28.4 \\
(1.6)\end{array}$ & $<0.6$ & $<0.6$ & $0.6 \pm 0.2$ \\
\hline${ }^{228} \mathrm{Ra}$ & $\begin{array}{c}325.0 \pm 60 \\
(1.4)\end{array}$ & $\begin{array}{c}493.7 \pm 30.9 \\
(1.1)\end{array}$ & $\begin{array}{c}631.9 \pm 56.5 \\
(1.5)\end{array}$ & $1.7 \pm 0.2$ & $1.0 \pm 0.2$ & $2.3 \pm 0.2$ \\
\hline${ }^{228} \mathrm{Th}$ & $\begin{array}{c}470.0 \pm 34.2 \\
(1.2)\end{array}$ & $\begin{array}{c}482.1 \pm 29.8 \\
(1.2)\end{array}$ & $\begin{array}{c}512.3 \pm 39.8 \\
(1.3)\end{array}$ & $<1.7$ & $<1.4$ & $<2.0$ \\
\hline${ }^{40} \mathrm{~K}$ & $<788$ & $<590$ & $<632$ & & & \\
\hline Mean & $\mathbf{1 . 3}$ & $\mathbf{1 . 2}$ & $\mathbf{1 . 4}$ & - & - & - \\
\hline
\end{tabular}

\section{Conclusions}

Five BR valorization methods have been discussed in the current article. Results, summarizing activity concentration for residues produced by every method are presented in the Figure 7 with corresponding measurement uncertainties. The presented results correspond to the mean value for secondary residues, averaged between multiple experiments (for example 3 experiments averaged for reductive smelting, 8 for alkali leaching). It should be noted, that all the materials studied have been produced using bauxite residue coming from AoG plant, which utilizes specific bauxite types. Therefore, results presented current study cannot be directly extrapolated to other plants or bauxite residues. 


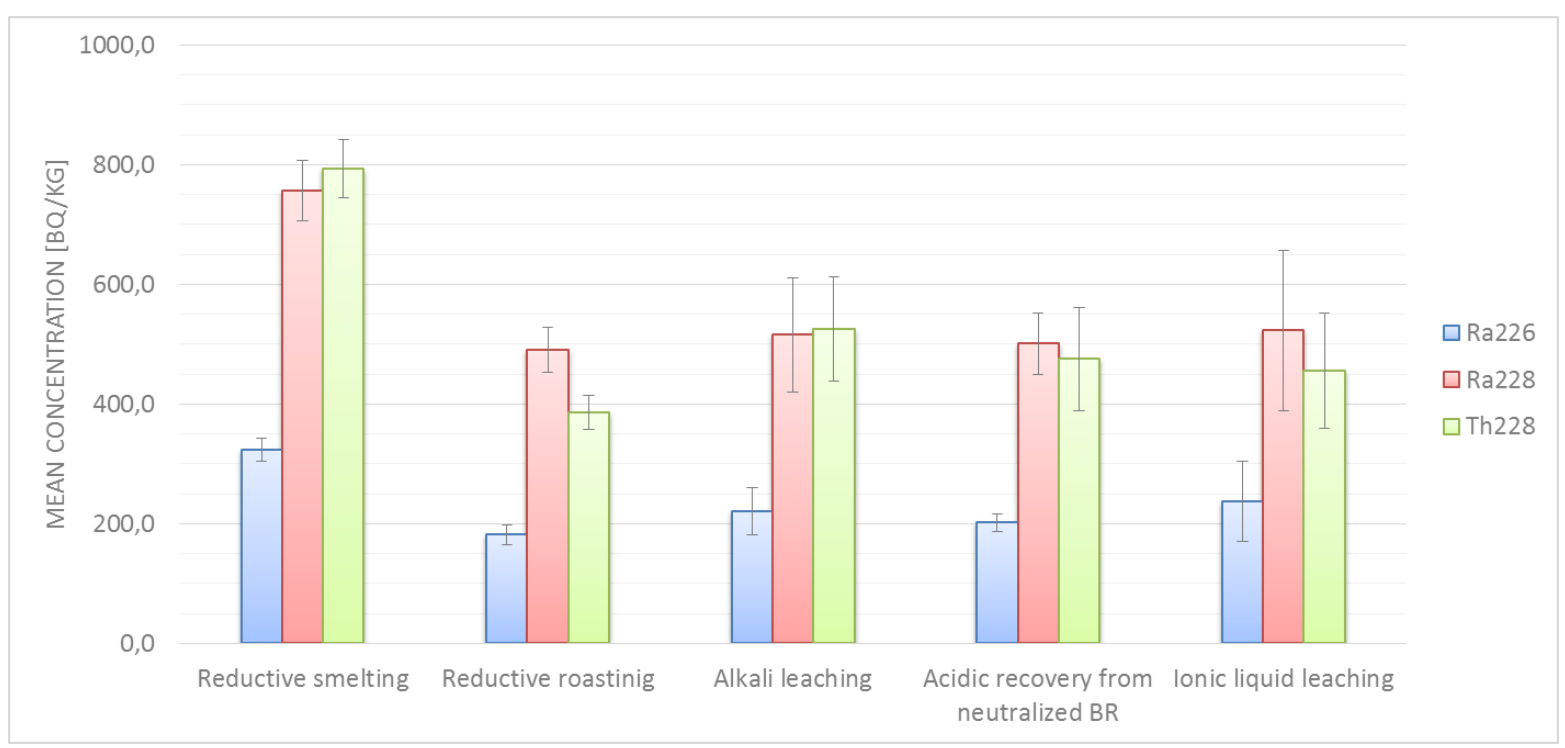

Figure 7: Radionuclide mean concentration ratios in secondary residues. Uncertainty bars are reported at $2 \sigma$.

It can be observed that all the results presented remain well below the screening values (1000 $\mathrm{Bq} / \mathrm{kg}$ for the nuclides measured) set in Euratom BSS. The exception from these findings was one particular experiment with reductive smelting; the screening value for ${ }^{228} \mathrm{Th}$ has been exceeded in the residue and ${ }^{210} \mathrm{~Pb}$ in the flue dust. The experiment was later optimized by utilizing flux materials and all subsequent residues remained below screening limits, while the flue dust is potentially hazardous residue that has to be dealt with. For the other studied valorization methods, this would be unnecessary as the radionuclide accumulation did not exceed EU BSS screening limits.

If a reductive smelting process were used on an industrial scale for BR from AoG, then a further radiological assessment might be needed to demonstrate safety of workers. However, it is expected that the standard protective safety measures utilized at a metallurgical plant (respirators, gloves, protective clothing) would be sufficient to provide a safe working environment from radiological perspective.

Additionally, measurements of ${ }^{40} \mathrm{~K}$ have been performed. Activity concentration of this radionuclide remained below minimum detectable amounts in all experiments except for one. All the provided results for this nuclide were below the EU BSS screening value set to 10 $\mathrm{kBq} / \mathrm{kg}$.

The current study has also shown that during iron recovery with microwave roasting, a considerable amount of radionuclides $\left({ }^{226} \mathrm{Ra},{ }^{228} \mathrm{Ra},{ }^{228} \mathrm{Th}\right)$ is recovered with iron, and during ionic liquid leaching, trace amounts of radionuclides $\left({ }^{226} \mathrm{Ra},{ }^{228} \mathrm{Ra}\right)$ were present in the leachate solution. 


\section{ACKNOWLEDGEMENTS}

The research leading to these results has received funding from the European Community's Horizon 2020 Programme (H2020/2014-2019) under Grant Agreement no. 636876 (MSCAETN REDMUD). This publication reflects only the authors' view, exempting the Community from any liability. Project website: http://www.etn.redmud.org.

The authors are grateful to B. Xakalashe, B. Friedrich, C. Bonomi, D. Panias, A. Dilipaltos, C. Cardenia, I. Paspaliaris, R. M. Rivera, T. Van Gergen, and P. T. Wai for providing residue samples and support in this work. 


\section{References}

Bonomi, C., Alexandri, A., Vind, J., Panagiotopoulou, A., Tsakiridis, P., Panias, D., 2018. Scandium and Titanium Recovery from Bauxite Residue by Direct Leaching with a Brønsted Acidic Ionic Liquid. Metals (Basel). 8, 834. https://doi.org/10.3390/met8100834

Bonomi, C., Cardenia, C., Yin, P.T.W., Panias, D., 2016. Review of Technologies in the Recovery of Iron , Aluminium , Titanium and Rare Earth Elements from Bauxite Residue ( Red Mud ) Review of Technologies in the Recovery of Iron , Aluminium , Titanium and Rare Earth Elements from Bauxite Residue ( Red Mud ). 3rd Int. Enhanc. Landfill Min. | Lisbon - Port. 4, 259-276. https://doi.org/10.5281/zenodo.571694

Bonomi, C., Davris, P., Balomenos, E., Giannopoulou, I., 2017. Ionometallurgical Leaching Process of Bauxite Residue : a Comparison between Hydrophilic and Hydrophobic lonic Liquids. 35th Int. ICSOBA Conf. Hamburg, Ger. 2 - 5 October, 2017 557-564.

Cardenia, C., Xakalashe, B., Balomenos, E., Panias, D., 2017. Reductive Roasting Process for the Recovery of Iron Oxides from Bauxite Residue through Rotary Kiln Furnace and Magnetic Separation. 35th Int. ICSOBA Conf. Hamburg, Ger. 2 - 5 October, 2017 595602.

De Araújo, J.A., Schalch, V., 2014. Recycling of electric arc furnace (EAF) dust for use in steel making process. J. Mater. Res. Technol. 3, 274-279. https://doi.org/10.1016/j.jmrt.2014.06.003

European Parliament, 2014. Council Directive 2013/59/Euratom of 5 December 2013 laying down basic safety standards for protection against the dangers arising from exposure to ionising radiation, and repealing Directives 89/618/Euratom, 90/641/Euratom, 96/29/Euratom, 97/43/Euratom a. Off J Eur Commun L13 1-73.

Evans, K., 2016. The History, Challenges, and New Developments in the Management and Use of Bauxite Residue. J. Sustain. Metall. 2, 316-331. https://doi.org/10.1007/s40831-0160060-x

Frik, E., 2016. Major tailings dam burst reported in China [WWW Document]. URL http://www.mining.com/major-tailings-burst-reported-in-china/

Goronovski, A., Vind, J., Vassiliadou, V., Panias, D., Tkaczyk, A.H., 2018. Radiological assessment of the Bayer process. Miner. Eng.

IAEA, 2003. Extent of Environmental Contamination by Naturally Occurring Radioactive Material (NORM) and Technological Options for Mitigation, La Prensa medica mexicana. Vienna.

IAEA, 1987. Preparation and certification of IAEA gamma-ray spectrometry reference materials RGU-1, RGTh-1 and RGK-1. laea-RI-148 48.

International Aluminium Institute, 2015. Bauxite Residue Management: Best Practice www.european-aluminium.

Jia, G., 2013. The radiological impact of $210 \mathrm{~Pb}$ and $210 \mathrm{Po}$ released from the iron- and steelmaking plant ILVA in taranto (Italy) on the environment and the public. J. Chem. 2013. https://doi.org/10.1155/2013/964310

Joyce, P.J., Hertel, T., Goronovski, A., Tkaczyk, A.H., Pontikes, Y., Björklund, A., 2018. Identifying hotspots of environmental impact in the development of novel inorganic polymer paving blocks from bauxite residue. Resour. Conserv. Recycl. 138, 87-98. 
https://doi.org/10.1016/j.resconrec.2018.07.006

Power, G., Gräfe, M., Klauber, C., 2009. Review of Current Bauxite Residue Management , Disposal and Storage : Practices, Engineering and Science.

Raj, R.R., Pillai, E.B.P., Santhakumar, A.R., 2013. Evaluation and mix design for ternary blended high strength concrete. Procedia Eng. 51, 65-74. https://doi.org/10.1016/j.proeng.2013.01.012

Rivera, R.M., Ounoughene, G., Borra, C.R., Binnemans, K., Van Gerven, T., 2017. Neutralisation of bauxite residue by carbon dioxide prior to acidic leaching for metal recovery. Miner. Eng. 112, 92-102. https://doi.org/10.1016/j.mineng.2017.07.011

Ruiz, O., Clemente, C., Alonso, M., Alguacil, F.J., 2007. Recycling of an electric arc furnace flue dust to obtain high grade ZnO. J. Hazard. Mater. 141, 33-36. https://doi.org/10.1016/j.jhazmat.2006.06.079

Ruyters, S., Mertens, J., Vassilieva, E., Dehandschutter, B., Poffijn, A., Smolders, E., 2011. The red mud accident in Ajka (Hungary): Plant toxicity and trace metal bioavailability in red mud contaminated soil. Environ. Sci. Technol. 45, 1616-1622. https://doi.org/10.1021/es104000m

Statiscal data published at the World Aluminium webpage. [WWW Document], n.d. URL http://www.world-aluminium.org/statistics/\#data (accessed 11.21.18).

Tam, P., Yin, W., Xakalashe, B., Friedrich, B., Panias, D., 2017. Carbothermic Reduction of Bauxite Residue for Iron Recovery and Subsequent Aluminium Recovery from Slag Leaching. 35th Int. ICSOBA Conf. Hamburg, Ger. 2 - 5 October, 2017 603-614.

Vidmar, T., 2005. EFFTRAN-A Monte Carlo efficiency transfer code for gamma-ray spectrometry. Nucl. Instruments Methods Phys. Res. Sect. A Accel. Spectrometers, Detect. Assoc. Equip. 550, 603-608. https://doi.org/10.1016/j.nima.2005.05.055

Vind, J., Vassiliadou, V., Panias, D., 2017. Distribution of Trace Elements Through the Bayer Process and its By-Products. 35th Int. ICSOBA Conf. Hamburg, Ger. 2 - 5 October, 2017 255-267.

Winkler, D., Bidló, A., Bolodár-Varga, B., Erdő, Á., Horváth, A., 2018. Long-term ecological effects of the red mud disaster in Hungary: Regeneration of red mud flooded areas in a contaminated industrial region. Sci. Total Environ. 644, 1292-1303. https://doi.org/10.1016/j.scitotenv.2018.07.059 